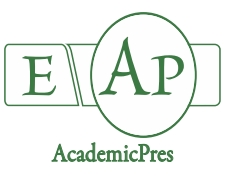

Oyeyinka BO and Afolayan AJ (2021)

Notulae Botanicae Horti Agrobotanici Cluj-Napoca

Volume 49, Issue 2, Article number 12262

DOI: $10.15835 /$ nbha 49312262

Research Article

\title{
Ultrastructure and energy dispersive spectroscopy-based elemental analysis of the fruit exocarps of Musa sinensis L. (Banana) and Musa paradisiaca L. (Plantain) (Musaceae)
}

\author{
Barnabas O. OYEYINKA, Anthony J. AFOLAYAN* \\ University of Fort Hare, Medicinal Plants and Economic Development (MPED) Research Centre, Botany Department, Alice 5700, \\ SouthAfrica; barnabastom@yahoo.com; aafolayan@ufh.ac.za ("corresponding author)
}

\begin{abstract}
Ultrastructural investigation and analysis of the elemental spectra composition of Musa sinensis L. and Musa paradisiaca L. exocarp (peels) was carried out using the Scanning Electron Microscopy (SEM) and Energy Dispersive X-Ray (EDX) respectively. Microstructures such as interlocked, polyhedral epidermal cells, ellipsoid-shaped stomata, guard cells, intercellular space, anticlinal-patterned walls and subsidiary cells were observed, with direct and indirect implications in the deposition of important primary and secondary metabolites, thus connoting some medicinal significance. Furthermore, the energy dispersive $\mathrm{x}$-ray spectra revealed the presence of some important elements such as potassium $(\mathrm{K})$, iron $(\mathrm{Fe})$, carbon $(\mathrm{C})$, oxygen $(\mathrm{O})$, silicon $(\mathrm{Si})$ and gold $(\mathrm{Au})$, with high to relatively high carbon and oxygen peaks consistently observed in Musa sinensis and Musa paradisiaca. In the same vein, the relative similarity observed in the constituents of quite a number of the elemental spectra (carbon, oxygen, silicon, gold) in M. sinensis and M. paradisiaca peels, also reflects species relatedness between $M$. sinensis and $M$. paradisiaca.
\end{abstract}

Keywords: electron microscopy; exocarp; mineral element; Musa paradisiaca; Musa sinensis; ultrastructure

\section{Introduction}

The Musa genus, an extraction of the Musaceae family is chiefly membered by $M$. sinensis and $M$. paradisiaca. They have original nativity in south-eastern Asia, with distribution in several parts of the tropics and subtropics (Ploetz et al., 2007; Nayar et al., 2010). M. sinensis and M. paradisiaca have economically and nutritionally important fruits due to their staple diet status, which also earns them their ethnomedicinal value (Sampath Kumar, 2012; Pereira and Maraschin, 2015). M. sinensis and M. paradisiaca possess seedless fruits (Figure 1). The fruit fingers are collectively arranged, forming bunches, with each fruit covered and protected by an outer skin referred to as the peel (exocarp). Medicinal plants are notably known to generate series of bioactive principles, which function in antioxidant, antimicrobial, antidiabetic, anti-inflammatory and anticarcinogenic capacities, with lowered risk of side effects as opposed to synthetic medicine (Negi et al., 2011; Dey and De, 2015). However, natural product-derived medicines require standardization and dose regulation

Received: 11 Feb 2021. Received in revised form: 06 May 2021. Accepted: 24 May 2021. Published online: 28 Sep 2021.

From Volume 49, Issue 1, 2021, Notulae Botanicae Horti Agrobotanici Cluj-Napoca journal uses article numbers in place of the traditional method of continuous pagination through the volume. The journal will continue to appear quarterly, as before, with four annual numbers. 
in order to ensure safety (Cheuka et al., 2016). Over time, these medicinal potentials have metamorphosed into increasing interest in the frontiers of natural, plant-based preclinical drug development.

Electron microscopy as a technique in ultrastructural frontiers possesses greater spatial resolution above the light microscopy (da Silva et al., 2009) which brings higher cutting-edge ultrastructural viewing and identity, which is useful for medicinally relevant plants. Furthermore, electron microscopy has also found some applicability in forensic analysis (Vermeij, 2008).

The nutritional and medicinal potentials in fruit peels have been variously reported (Maniyan et al., 2015; Pereira and Maraschin, 2015; Feumba et al., 2016; Sidhu and Zafar, 2018; Kothawade, 2019; Oyeyinka and Afolayan, 2019; Oyeyinka and Afolayan, 2020), including secondary metabolite deposition and accumulation in fruit coverings and their microstructures (Hammouda et al., 2014; Tessmer et al., 2014). Nevertheless, more insights into the ultra-morphological body of knowledge related to the exocarps of $M$. sinensis and $M$. paradisiaca fruits, as well as species relatedness are still essential. This study was thus designed to examine the electron microscopic ultra-morphology of the exocarps of two prominent Musaceae fruits, with a view to identify complex ultra-features, elemental spectra, as well as their possible functional roles as depositories of primary and secondary metabolites of pharmacological value. This is in turn, an attempt to increase the incorporation and utility of $M$. sinensis and $M$. paradisiaca exocarps in human nutrition.

\section{Materials and Methods}

\section{Plant (sample) collection and authentication}

Fruits of banana (M. sinensis) and plantain (M. paradisiaca) used in this study were obtained from supermarkets in Alice and East London respectively, both located in Amathole District Municipality of the Eastern Cape Province, South Africa. These areas lie at $32^{\circ} 43^{\prime} 28.66^{\prime \prime}$ and $26^{\circ} 34^{\prime} 5.88^{\prime \prime}$ geographical latitude and longitude, respectively. Professor C.N. Cupido, a taxonomist in the Botany department, University of Fort Hare (UFH), authenticated the peel samples of $M$. sinensis and $M$. paradisiaca and voucher specimens (UFH2019-11-001 and UFH-2019-12-002) respectively, were deposited in the herbarium.

\section{Fixation and drying}

The method described by Asowata-Ayodele et al. (2016) was employed with slight modification. Descriptively, fresh peel samples $(2 \mathrm{~mm}$ ) of banana and plantain were cut and fixed for 96 hours (at least 24 hours) in $6 \% \mathrm{w} / \mathrm{v}$ gluteraldehyde (buffered with sodium cacodylate $\mathrm{pH} 7.3$ ), in order to enhance sample penetrability during electron microscopy. Each peel sample was rinsed in distilled water to eliminate extraneous fixative material and subsequently dried in ten ethanol concentration gradients $(10 \%, 20 \%, 30 \%, 40 \%, 50 \%$, $60 \%, 70 \%, 80 \%, 90 \%$ and $100 \%$ ) for a 20 minute-duration per concentration gradient (Munien et al., 2015).

\section{SEM and EDX Spectra Ultrastructural Capture}

M. sinensis and M. paradisiaca peel samples were dried via the Hitachi HCP-2 critical point dryer and mounted on aluminium stubs. The Argon baseline, otherwise referred to as the gold palladium gas was supplied to the critical point dryer for sample drying. This process essentially presents an ideal conducting gold material, including the prevention of surface charging, promotion of even conduction and homogeneity in the sample surface, in order to obtain better quality, high resolution imaging (Leslie and Mitchell, 2007). The peel samples were then examined at different magnification levels, ranging from $(\times 100$ to $\times 1000)$ in $M$. sinensis and $(\times 100$ to $\times 1800$ ) in $M$. paradisiaca, with the JEOL (JSM-6390LV) scanning electron microscope, powered at $15 \mathrm{kV}$ accelerated voltage. Electron images and EDX spectra were captured via the Scanning Electron Microscope (SEM) Noran system six imaging software and its structural component the Energy Dispersive X-ray analyser (Thermo Electron Corporation, 6733B-IUUSN, USA) respectively (Sharaibi and Afolayan, 2017). 


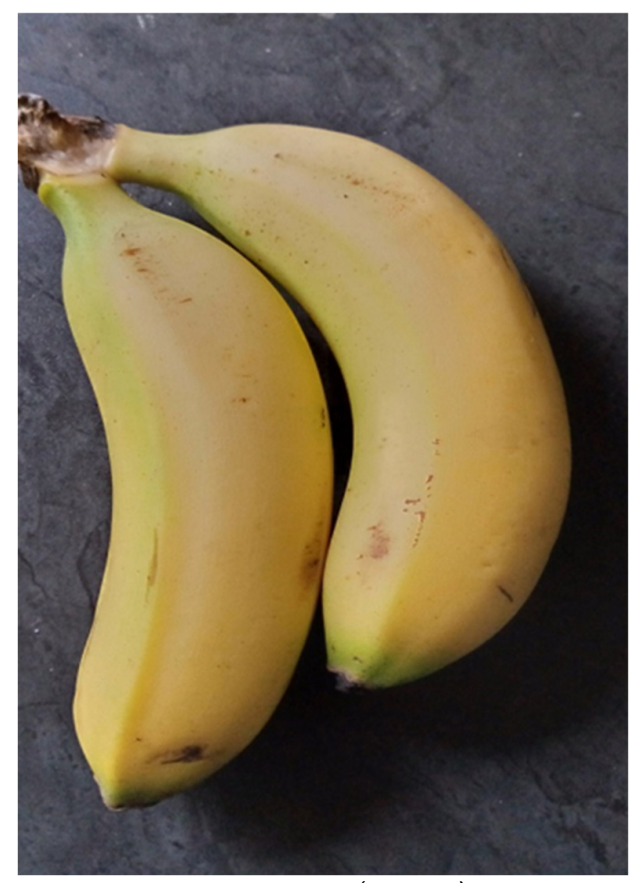

Musa sinensis (Banana)

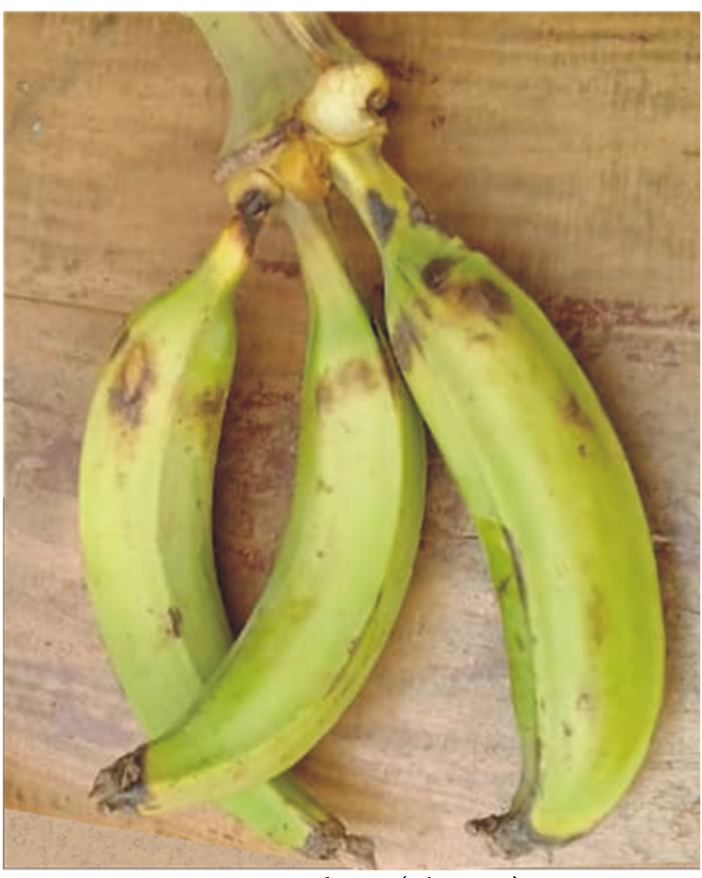

Musa paradisiaca (Plantain)

Figure 1. Photos of the fruits of $M$. sinensis and M. paradisiaca

\section{Results}

Ultrastructural analysis and energy dispersive $X$-Ray elementals spectra

The ultrastructural microscopic evaluation of revealed randomly arranged, elliptical shaped stomatal structures in M. sinensis and M. paradisiaca exocarps (Figure 2e, 3b, 3c, 3d and 3e). Furthermore, guard cells (components to stomata structure) and subsidiary cells were observed in $M$. sinensis and $M$. paradisiaca (Figure $2 \mathrm{e}, 3 \mathrm{c}, 3 \mathrm{~d}, 3 \mathrm{e}$ ). There were regular to irregular interlockings of angular epidermal cells (Figure 2e, 3d, $3 \mathrm{f}$ and $3 \mathrm{~g}$ ), with particular polyhedral (pentagonal) structure identified in $M$. paradisiaca (Figure 3d). Tiny to small intercellular spaces were identified in M. sinensis and M. paradisiaca (Figure 2e and 3d). Furthermore, cells were closely packed with anticlinal walls identified in $M$. sinensis and $M$. paradisiaca (Figure $2 \mathrm{c}, 2 \mathrm{f}$ and $3 \mathrm{~g}$ ). The energy dispersive $\mathrm{x}$-ray (EDX) analysis revealed the spectra presence of elements such as carbon (C), oxygen $(\mathrm{O})$, silicon $(\mathrm{Si})$ and gold $(\mathrm{Au})$ on $M$. sinensis and $M$. paradisiaca exocarp, with the inclusion of the potassium and iron in M. sinensis. The corresponding peaks of the profiled elements in M. sinensis and M. paradisiacaby EDX spectra are presented in Figure 4 and 5, with high and relatively high carbon and oxygen peaks respectively in both exocarp samples. Table 1 presents the elemental proportions (atomic \%) in the exocarp of $M$. sinensis and $M$. paradisiaca. 

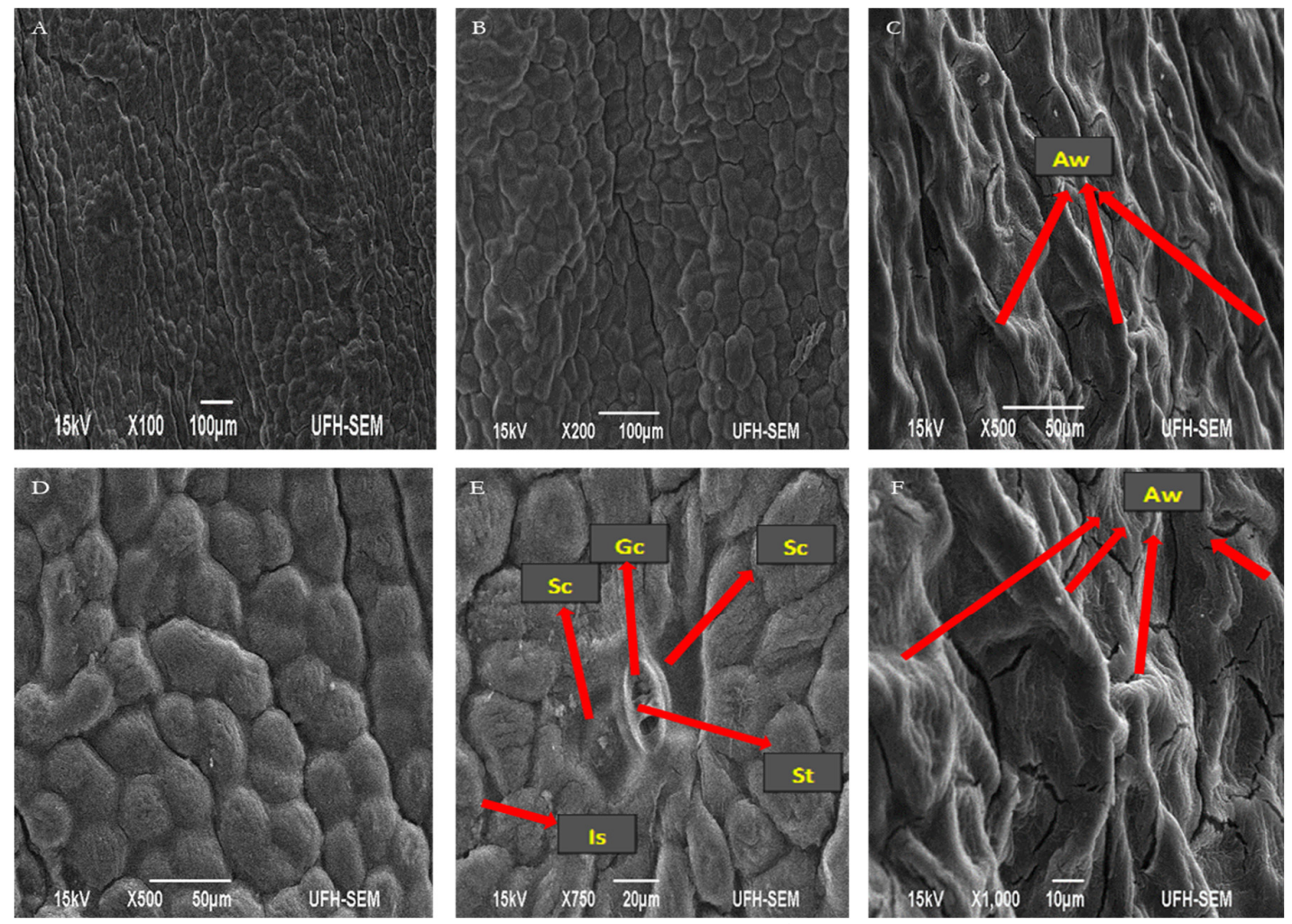

Figure 2. Micrographs and ultrastructure of $M$. sinensis exocarp (peel)

(A) relatively homogenous epidermal surface $[100 \mathrm{X}]$ (B) homogenous, with somewhat anticlinal epidermal surface [200X] (C) anticlinal walls (AW) [500X] (D) [500X] (E) epidermal cells (EC), stomata (ST), guard cells (GC), subsidiary cells (SC), intercellular space (IS) [750X] (F) anticlinal walls (AW) [1,000X].
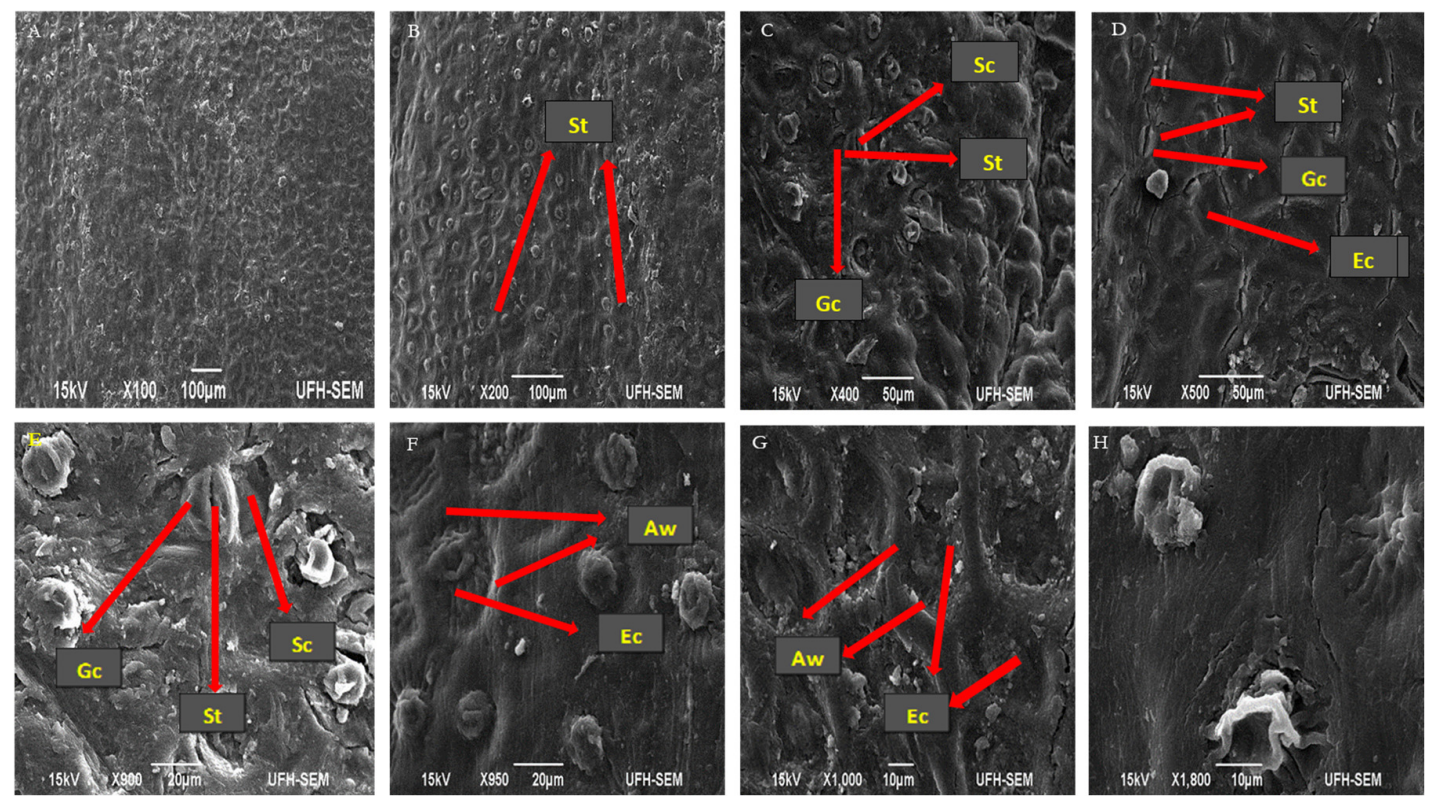

Figure 3. Micrographs and ultrastructure of $M$. paradisiaca exocarp (peel)

(A) relatively homogenous epidermal surface [100X] (B) stomata (ST) [200X] (C) stomata (ST), guard cell (GC), subsidiary cell (SC) [400X] (D) epidermal cells (EC), intercellular space (IS), stomata (ST) and guard cell (GC) [500X] (E) stomata (ST), guard cell (GC) [900X] (F) epidermal cell (EC), anticlinal walls (AW) [950X] (G) epidermal cell (EC) with anticlinal walls $[1,000 \mathrm{X}](\mathrm{H})[1,800 \mathrm{X}]$ 

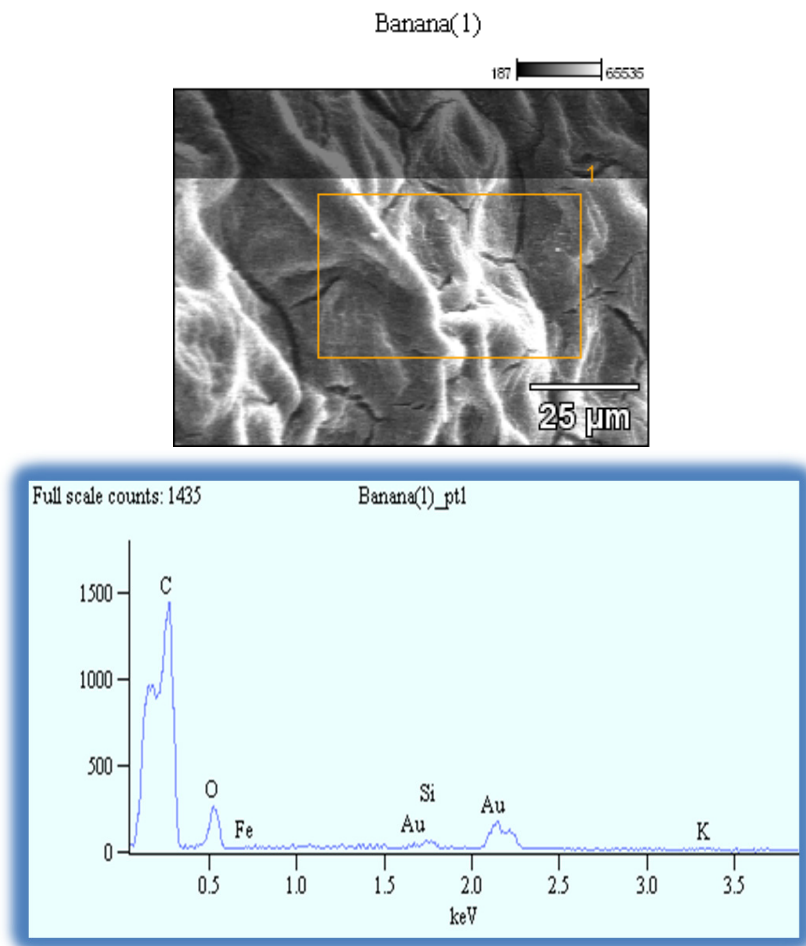

Figure 4. Energy Dispersive X-Ray (EDX) spectra of elements identified in M. sinensis L. exocarp (peel), indicating intensity or counts of the elemental spectra ( $\mathrm{y}$-axis) and the accelerating voltage ( $15 \mathrm{keV}$ energy) on the $\mathrm{x}$-axis

Plaintain(1)
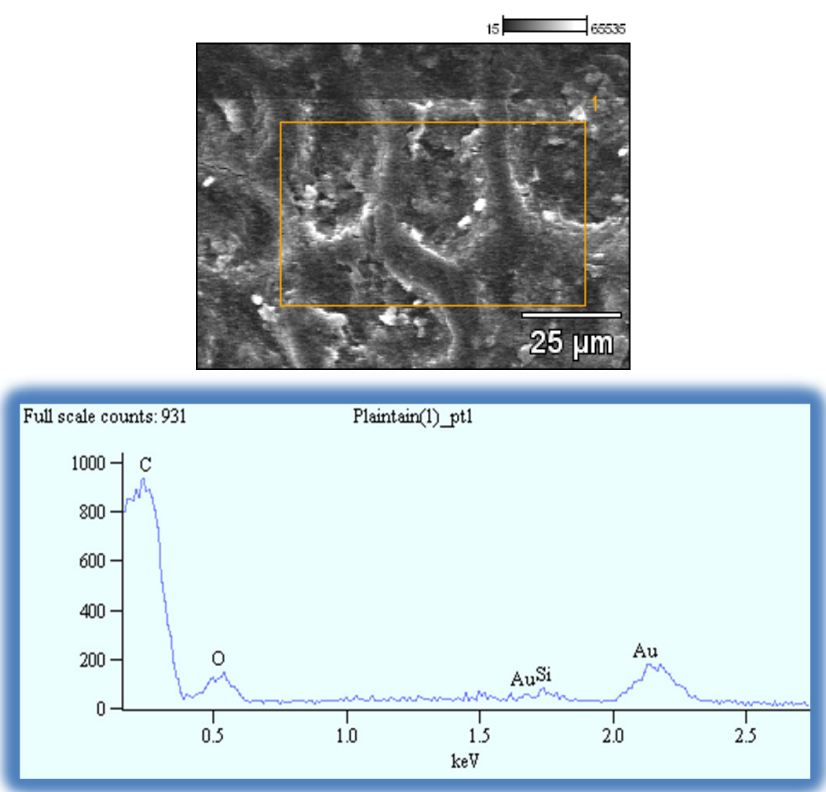

Figure 5. Energy Dispersive X-Ray (EDX) spectra of elements identified in $M$. paradisiaca L. exocarp (peel) indicating intensity or counts of the elemental spectra (y-axis) and the accelerating voltage (15 keV energy) on the $\mathrm{x}$-axis 
Table 1. Energy dispersive X-ray elemental spectra by weight (\%) of $M$. sinensis and $M$. paradisiaca exocarps

\begin{tabular}{|l|c|c|}
\hline \multicolumn{1}{|c|}{ Element } & M. sinensis & M. paradisiaca \\
\hline Carbon & $67.15 \pm 1.42$ & $59.01 \pm 1.77$ \\
\hline Oxygen & $12.24 \pm 1.17$ & $11.85 \pm 1.04$ \\
\hline Silicon & $1.14 \pm 0.12$ & $1.12 \pm 0.14$ \\
\hline Gold & $18.03 \pm 10.81$ & $28.02 \pm 12.77$ \\
\hline Potassium & $0.87 \pm 0.15$ & \\
\hline Iron & $0.56 \pm 0.44$ & \\
\hline
\end{tabular}

\section{Discussion}

Fruit exocarps are hydrophobic structures that are responsible for physiological functions such as desiccation limitation, protection against microbial infection and preservation of fruit palatability (Martin and Rose, 2014). In this study, microstructures such as the epidermal cells, guard cells and intercellular spaces identified in $M$. sinensis and $M$. paradisiaca exocarps are directly or indirectly linked to primary and secondary metabolite deposition, which in turn attributes pharmacological potentials to the peels (Hammouda et al., 2014; Tessmer et al., 2014; Konarska and Domaciuk, 2018; Konarska et al., 2018).

The epidermis, which houses the epidermal cells, has been identified as a key site for series of secondary metabolism pathways for flavonoids, alkaloids and terpenoids (Mahroug et al., 2005). They are also exuders of secondary metabolite substances like flavonoid aglycones (Svoboda et al., 2001), which is indicative of polyphenolic constitution and pharmacological activity in banana and plantain exocarps (Oyeyinka and Afolayan, 2019; Oyeyinka and Afolayan, 2020). Epidermal cell wall microstructures identified in $M$. sinensis and $M$. paradisiaca exocarps signify potential storehouses of primary metabolite carbohydrates, in relation to previous reports of polysaccharides isolated in banana (Amnuaysin et al., 2020). This is in relation to the microscopy study of Ellis et al. (2004) which reports mineral nutrient storage in cell compartments, with cell walls identified with lipid primary metabolite bioaccessibility.

The intercellular spaces in $M$. sinensis and $M$. paradisiaca exocarps may be potentially relevant in essential oil secretion based on reports of the possible implication of their secretory cell linings (Svoboda et al., 2001). Guard cells housed in the epidermal region in land plants and possess stomatal regulatory mechanisms (Jin et al., 2013). Polyphenolic compounds in conjugation with polysaccharides and proteins have been identified to be bound in the chloroplast, which are a relatedly localized in the guard cells (Parada and Aguilera, 2007). The guard cell microstructures in $M$. sinensis and $M$. paradisiaca exocarps are further indicators of primary metabolite (carbohydrate), based on previous works reporting the location of starch therein (Talbott and Zeiger, 1993; Azoulay-Shemer et al., 2016).

Based on the high carbon peaks in the elemental spectra of $M$. sinensis and M. paradisiaca exocarps, indications are linked towards the possible constitution of calcium oxalate and calcium sulphate (Otang et al., 2014) which are one of the most abundantly formed minerals in plants (Franceschi and Nakata, 2005).

The presence of Oxygen in the EDX spectra analysis indicates the derivative presence of primary metabolites fiber, carbohydrate and protein in banana and plantain peels (Essien et al., 2005; Kamsonlian et al., 2011; Oyeyinka and Afolayan, 2019). Carbon on the other hand, is a central component of carbohydrates, lipids and protein, including phytoorganic compounds (Soetan et al., 2010). Silicon is a trace element regarded as "quasi-beneficial" and non-essential and is generally accumulated more in monocots (Korndorfer and Lepsch, 2001; Richmond and Sussman, 2003; Bhat et al., 2019). Potassium is a major element that is implicated in protein synthesis, enzyme activation and the mechanism of stomata operation, while iron, another trace element functions in the synthesis process of chlorophyll (Soetan et al., 2010).

Previous reports have identified the implication of similarity in epidermal elemental constitution, in plant delineation and relatedness (Hartley et al., 2015). In this study, the relative similarity of most of the 
elemental constituents (carbon, oxygen, silicon, gold) in $M$. sinensis and $M$. paradisiaca peels, could indicate species relatedness, in corroboration with the ultrastructural study of Olatunji and Afolayan (2020). The significantly high constitution of gold in the exocarp of $M$. sinensis and $M$. paradisiaca could be linked to spur plating sputter coating process of samples (Olatunji and Afolayan, 2020).

\section{Conclusions}

The ultrastructural evidence of $M$. sinensis and M. paradisiaca exocarp reflects the significance of the microstructures such as guard cells, stomata, intercellular space and anticlinal walls in relation to physiological functioning and mechanism, as well as nutritive value on the basis of the elemental constituents in the spectra of the epidermal compartments of the exocarp. This electron microscopy and EDX study further suggests that epidermal characters identified therein are relevant in contributing to the morphological identity of Musa species and as well, the dietary incorporation potentials of fruit peels in human nutrition.

\section{Authors' Contributions}

Conceptualization: B.O.O. and A.J.A.; Data curation: B.O.O.; Formal analysis: B.O.O.; Funding acquisition: A.J.A.; Investigation: B.O.O.; Methodology: B.O.O. and A.J.A.; Project administration: A.J.A.; Resources: A.J.A.; Software: A.J.A.; Supervision: A.J.A.; Validation: A.J.A.; Visualization: B.O.O. and A.J.A.; Writing - original draft: B.O.O.; Writing - review and editing: B.O.O. and A.J.A. Both authors read and approved the final manuscript.

\section{Acknowledgements}

This work was supported by Govan Mbeki Research and Development Centre (GMRDC), University of Fort Hare, South Africa.

\section{Conflict of Interests}

The authors declare that there are no conflicts of interest related to this article.

\section{References}

Amnuaysin N, Seraypheap K, Kidyoo M (2020). Delayed softening of 'Hom Thong' banana fruits during postharvest storage following hot water treatment. Songklanakarin Journal of Science and Technology 1-26.

Asowata-Ayodele AM, Afolayan AJ, Otunola GA (2016). Foliar micromorphology of Lippia javanica (Burm. F) Spreng. African Journal of Traditional, Complementary and Alternative Medicines 13(2):237-242. https://doi.org/10.4314/ajtcam.v13i2.28

Azoulay-Shemer T, Bagheri A, Wang C, Palomares A, Stephan AB, Kunz H, Schroeder JI (2016). Starch biosynthesis in guard cells but not in mesophyll cells is involved in $\mathrm{CO}_{2}$-induced stomatal closing. Plant Physiology 171(2):788798. https://doi.org/10.1104/pp.15.01662

Bhat JA, Shivaraj SM, Singh P, Navadagi DB, Tripathi DK, Dash PK, ... Deshmukh R (2019). Role of silicon in mitigation of heavy metal stresses in crop plants. Plants 8(3):1-20. https://doi.org/10.3390/plants8030071 
Cheuka PM, Mayoka G, Mutai P, Chibale K (2016). The role of natural products in drug discovery and development against neglected tropical diseases. Molecules 22(1):58. https://doi.org/10.3390/molecules22010058

da Silva G, Taniça M, Gomes ET, Serrano R, Silva O (2009). Morpho-anatomy and histochemistry of Maytenus heterophylla leaf, an African medicine. Planta Medica 75(9):994-999. https://doi.org/10.1055/s-00291234666

Dey A, De JN (2015). Neuroprotective therapeutics from botanicals and phytochemicals against Huntington's disease and related neurodegenerative disorders. Journal of Herbal Medicine 5(1):1-19. https://doi.org/10.1016/j.hermed.2015.01.002

Ellis PR, Kendall CWC, Ren Y, Parker C, Pacy JF, Waldron KW, Jenkins DJA (2004). Role of cell walls in the bioaccessibility of lipids in almond seeds. The American Journal of Clinical Nutrition 80(3):604-613. https://doi.org/10.1093/ajcn/80.3.604

Essien JP, Akpan EJ, Essien EP (2005). Studies on mould growth and biomass production using waste banana peel. Bioresource Technology 96(13):1451-1456. https://doi.org/10.1016/j.biortech.2004.12.004

Feumba DR, Ashwini RP, Ragu SM (2016). Chemical composition of some selected fruit peels. European Journal of Food Science and Technology 4(4):12-21.

Franceschi VR, Nakata PA (2005). Calcium oxalate in plants: formation and function. Annual Review of Plant Biology 56:41-71. https://doi.org/10.1146/annurev.arplant.56.032604.144106

Hammouda H, Alvarado C, Bouchet B, Kalthoum-Chérif J, Trabelsi-Ayadi M, Guyot S (2014). Tissue and cellular localization of tannins in Tunisian dates (Phoenix dactylifera L.) by light and transmission electron microscopy. Journal of Agricultural and Food Chemistry 62(28):6650-6654. https://doi.org/10.1021/jf5013715

Hartley SE, Fitt RN, Mc Larnon EL, Wade RN (2015). Defending the leaf surface: intra-and inter-specific differences in silicon deposition in grasses in response to damage and silicon supply. Frontiers in Plant Science 6(35):1-8. https://doi.org/10.3389/fpls.2015.00035

Jin X, Wang R, Zhu M, Jeon BW, Albert R, Chen S, Assmann SM (2003). Abscisic acid-responsive guard cell metabolomes of Arabidopsis wild-type and gpal G-protein mutants. The Plant Cell 25(12):4789-4811. https://doi.org/10.1105/tpc.113.119800

Kamsonlian S, Suresh S, Majumder CB, Chand S (2011). Characterization of banana and orange peels: biosorption mechanism. International Journal of Technology Management 2(4):1-7.

Konarska A (2018). Microstructural and histochemical characteristics of Lycium barbarum L. fruits used in folk herbal medicine and as functional food. Protoplasma 255(6):1839-1854. https://doi.org/10.1007/s00709-018-1277-2

Konarska A, Domaciuk M (2018). Differences in the fruit structure and the location and content of bioactive substances in Viburnum opulus and Viburnum lantana fruits. Protoplasma 255:25-41. https://doi.org/10.1007/s00709017-1130-Z

Korndörfer GH, Lepsch I (2001). Chapter 7: Effect of silicon on plant growth and crop yield. Studies in Plant Science 8:133-147. https://doi.org/10.1016/S0928-3420(01)80011-2

Kothawade CV (2019). Medicinal and nutritional importance of Banana. Acta Scientific Agriculture 3:29-33.

Leslie SA, Mitchell JC (2007). Removing gold coating from SEM samples. Palaeontology 50(6):1459-1461. https://doi.org/10.1111/j.1475-4983.2007.00718.x

Mahroug S, Courdavault V, Thiersault M, St-Pierre B, Burlat V (2005). Epidermis is a pivotal site of at least four secondary metabolic pathways in Catharanthus roseus aerial organs. Planta 223:1191-1200. https://doi.org/10.1007/s00425-005-0167-y

Maniyan A, John R, Mathew A (2015). Evaluation of fruit peels for some selected nutritional and anti-nutritional factors. Emergent Life Sciences Research 1(2):13-19.

Martin LBB, Rose JKC (2014). There's more than one way to skin a fruit: formation and functions of fruit cuticles. Journal of Experimental Botany 65(16):4639-4651. https://doi.org/10.1093/jxb/eru301

Munien P, Naidoo Y, Naidoo G (2015). Micromorphology, histochemistry and ultrastructure of the foliar trichomes of Withania somnifera (L.) Dunal (Solanaceae). Planta 242(5):1107-1122. https://doi.org/10.1007/s00425-0152341-1

Nayar NM (2010). The bananas: botany, origin, dispersal. Horticultural Reviews 36:117-164. https://doi.org/10.1007/s00425-015-2341-1

Negi JS, Singh P, Rawat B (2011). Chemical constituents and biological importance of Swertia: A review. Current Research in Chemistry 3:1-15. https://doi.org/10.3923/crc.2011.1.15 
Olatunji TL, Afolayan AJ (2020). Comparative foliar epidermal studies in Capsicum annuum L. and Capsicum frutescens L. Journal of Tropical Agriculture 58(1):60-67.

Otang WM, Grierson DS, Ndip R (2014). Foliar micro-morphology of Gasteria bicolor Haw. (Asphodelaceae) from South Africa. African Journal of Traditional, Complementary and Alternative Medicines 11(4):71-76. https://doi.org/10.4314/ajtcam.v11i4.12

Oyeyinka BO, Afolayan AJ (2019). Comparative evaluation of the nutritive, mineral and antinutritive composition of Musa sinensis L. (Banana) and Musa paradisiaca L. (Plantain) fruit compartments. Plants 8(12):598. https://doi.org/10.3390/plants8120598

Oyeyinka BO, Afolayan AJ (2020). Comparative and correlational evaluation of the phytochemical constituents and antioxidant activity of Musa sinensis L. and Musa paradisiaca L. fruit compartments (Musaceae). The Scientific World Journal 2020:1-12. https://doi.org/10.1155/2020/4503824

Parada J, Aguilera JM (2007). Food microstructure affects the bioavailability of several nutrients. Journal of Food Science 72(2):R21-R32. https://doi.org/10.1111/j.1750-3841.2007.00274.X

Pereira A, Maraschin M (2015). Banana (Musa spp) from peel to pulp. Ethnopharmacology, source of bioactive compounds and its relevance for human health. Journal of Ethnopharmacology 160:149-163. https://doi.org/10.1016/j.jep.2014.11.008

Ploetz RC, Kepler AK, Daniells J, Nelson SC (2007). Banana and plantain-an overview with emphasis on Pacific Island cultivar Musaceae (banana family). In: Species Profiles for Pacific Island Agroforestry, pp 1-27.

Richmond KE, Sussman M (2003). Got silicon? The non-essential beneficial plant nutrient. Current Opinion in Plant Biology 6(3):268-272. https://doi.org/10.1016/s1369-5266(03)00041-4

Sampath Kumar KP, Bhowmik D, Duraivel S, Umadevi M (2012). Traditional and medicinal uses of banana. Journal of Pharmacognosy and Phytochemistry 1(3):51-63.

Sharaibi OJ, Afolayan AJ (2017). Micro-morphological characterization of the leaf and rhizome of Agapanthus praecox subsp. Praecox Willd. (Amaryllidaceae). Journal of Botany 2017:1-10. https://doi.org/10.1155/2017/3075638

Sidhu JS, Zafar TA (2018). Bioactive compounds in banana fruits and their health benefits. Food Quality and Safety 2(4):183-188. https://doi.org/10.1093/fqsafe/fyy019

Soetan KO, Olaiya CO, Oyewole OE (2010). The importance of mineral elements for humans, domestic animals and plants: A review. African Journal of Food Science 4(5):200-222.

Svoboda KP, Juhasz A, Hampson JB (2001). Bioactivity of essential oils and their components- Eucalyptus. Aroma Research 2(2):88-93.

Talbott LD, Zeiger E (1993). Sugar and organic acid accumulation in guard cells of Vicia faba in response to red and blue light. Plant Physiology 102(4):1163-1169. https://doi.org/10.1104/pp.102.4.1163

Tessmer MA, Kluge RA, Appezzato-da-Glória B (2014). The accumulation of tannins during the development of 'Giombo' and 'Fuyu' persimmon fruits. Scientia Horticulturae 172(9):292-299. https://doi.org/10.1016/j.scienta.2014.04.023

Vermeij E (2008). Forensic applications of scanning electron microscopy, a brief overview. Forensic Science 20-30.

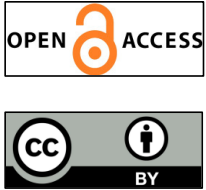

The journal offers free, immediate, and unrestricted access to peer-reviewed research and scholarly work. Users are allowed to read, download, copy, distribute, print, search, or link to the full texts of the articles, or use them for any other lawful purpose, without asking prior permission from the publisher or the author.

License - Articles published in Notulae Botanicae Horti Agrobotanici Cluj-Napoca are Open-Access, distributed under the terms and conditions of the Creative Commons Attribution (CC BY 4.0) License. (c) Articles by the authors; UASVM, Cluj-Napoca, Romania. The journal allows the author(s) to hold the copyright/to retain publishing rights without restriction. 